\title{
NATIONAL DEVELOPMENT PROGRAM ACCORDING TO THE MAQASHID SHARIAH
} PERSPECTIVES

\section{Rahmat Fajar ${ }^{1}$ Heni Noviarita ${ }^{2}$ Erike Anggraini $^{3}$ Surono $^{4}$}

Article history:

Submitted:

3 September 2020

Revised:

30 Januari 2021

Accepted:

23 Maret 2021

\section{Keywords:}

Maqasid Sharia;

Government Program;

Government Policy.

\section{Kata Kunci:}

Maqasid Syariah;

Program Pemerintah;

Kebijakan Pemerintah.

\section{Koresponding:}

Universitas Airlangga,

Surabaya, Jawa Timur,

Indonesia

Email:Surono-

2018@pasca.unair.ac.id
Abstract

Government is an important element in the development of a country, In Islam, a country's policy must encompass life in the world and the hereafter, this can be reviewed through the perspective of sharia maqashid. Therefore the purpose of this study is to look at Indonesian government programs in the Maqashid Syariah review. This study uses a descriptive qualitative approach where the data source used is Library Reseacrh. The results showed that the Indonesian government was able to make government policies in the form of various programs to solve problems and improve the welfare and development of Indonesia. From many of these programs, this research only discusses government programs that are in accordance with Maqashid Syariah. The results showed that Indonesia through its policies and government programs succeeded in maintaining 5 elements of Islamic maqashid namely hifdzun in (Religion), hifzhun nafs (Jiwal), hifdzul 'aql (Reason), hifzhun nasl (Descendants) and hifzhul maal (Wealth) where means that the Indonesian people are able to have the opportunity to achieve the good of the world and the hereafter.

Abstrak
Pemerintah merupakan elemen penting dalam pembangunan suatu Negara,
Dalam Islam kebijakan suatu negara harus mencakup kehidupan di dunia dan
akhirat, hal tersebut bisa ditinjau melalui perspektif maqashid syariah. Oleh
karena itu tujuan penelitian ini adalah untuk melihat program-program
pemerintah Indonesia dalam tinjauan Maqashid Syariah. Penelitian ini
menggunakan pendekatan kualitatif deskriptif dimana sumber data yang
digunakan merupakan kajian literatur. Hasil penelitian menunjukkan bahwa
pemerintah Indonesia mampu membuat kebijakan pemerintahan dalam
bentuk program-program yang beragam untuk menyelesaikan masalah dan
meningkatkan kesejahteraan serta pembangunan Indonesia. Dari banyak
program tersebut maka penelitian ini hanya membahas mengenai program
pemerintah yang sesuai dengan Maqashid Syariah. Hasil penelitian
menunjukkan bahwa Indonesia melalui kebijakan-kebijakan dan program
pemerintahannya berhasil memelihara 5 unsur maqashid syariah yaitu
hifdzun diin (Agama), hifzhun nafs (Jiwal), hifdzul 'aql (Akal), hifzhun nasl
(Keturunan) dan hifzhul maal (Kekayaan) dimana berarti masyarakat
Indonesia mampu berkesempatan untuk mencapai kebaikan dunia dan
akhirat.




\section{INTRODUCTION}

Indonesia is a vast unitary country with a rich diversity of human and natural resources, so it requires the right strategy in planning and implementing its development (Dahuri, 2001). Resource management in Indonesia is inseparable from the basic ideology of the Unitary State of the Republic of Indonesia, namely Pancasila. Suhardin, (2012), Pancasila as the basis of the state must be implemented in every program or strategy used in the development or achievement of the goals of the Indonesian state which must be based on the Almighty God, Prosperity for the Indonesian people, Indonesian unity, a society led by a just and civilized society, and social justice for all Indonesian people. Pancasila itself has points that are covered in the Maqashid Sharia, namely protecting religion, guarding the soul, maintaining reason, protecting descendants and protecting property. Both have the same goal, namely for the benefit. Ahmad (2011), Pancasila and maqashid syariah which aim for the benefit of humanity which are defined as everything related to human sustenance, fulfillment and acquisition of everything that is demanded by emotional and intellectual qualities, in an absolute sense.

The main purpose of sharia is to encourage the benefit (welfare) of humans which lies in the preservation of religion, life, reason, descent and wealth. Furthermore, anything that protects these five elements of the public interest is highly recommended. on the contrary, everything that threatens him must be eliminated (Chapra, 2000).
Pancasila contains 5 elements and aspects of Divinity, Humanity, Unity, Wisdom and Wisdom and Justice. Basically, the elements contained in Pancasila itself are very closely related to Islam, so it can be said that Islamic norms and values already exist and are contained and become the principles for Indonesian society in general. If demanded in accordance with Islamic norms and values in the Pancasila ideology, we will find that (Fuad, 2012):

The First Precept: One Godhead. This precept is found in the Koran, Surat Al Ikhlas verse 1. It means, "Say, he is Allah, the One. Second Sila: Just and Civilized Humanity. This precept is in the Alquran An Nisa 135. The translation is: "O you who believe. Be the enforcer of your justice, be a witness for God even though yourself or your mother and your father and your relatives. If he (the accused) is rich or poor, then Allah know more about the benefits (goodness). Then do not follow lust because you want to deviate from the truth. And if you turn away (words) or are reluctant to be a witness, then know that Allah is Checking everything you do. "

Meanwhile, the third precept is the Indonesian Unity. This precept is also in AlSurah Al- Hujurat verse 13. The translation is: "O people, We actually created you from a man and woman and made you a nation nation and tribe so that you know each other. The noblest among you by Allah is the most pious among you. Allah knows best. "This verse is very suiTable considering that Indonesia consists of various tribes.

Furthermore, in the fourth precept where democracy is led by the wisdom of wisdom in consultation / representation. This 
precept is also in the Koran as Shuro 38. The translation is: "And (for) those who accept (obey) the summons of their Rabb, and establish their prayers, their affairs are (decided) by deliberation among them; and they spend part of their wealth., which We gave them. "

The last precept is social justice for all Indonesian people. This precept is also found in the Koran in An Nahl verse 90. The translation is: "Surely Allah commands (humans) to do justice and do good, to give (alms) to relatives, and Allah forbids cruelty, evil and enmity. He teaches you ( people), so you can take lessons".

It that reinforce Islamic values contained even before Indonesia's independence, since the independence of Indonesia is inseparable from the role of scholars and Muslim hero (Ahmad, 2011). Thus maqashid sharia can be used as the main reference in the pace of development steps carried out, especially for a country, especially a country with a majority Muslim population. Indonesia, which is a predominantly Muslim country with the Pancasila ideology, both of which have the same goal, must have a development and development model that is beneficial to humanity or its society. So that in this study the researcher aims to analyze the development programs of the Indonesian government from various fields of economy, social, politics, religion, education, culture and so on in the review of maqashid Islam.

Maqashid Sharia in the language according to Al Syatibi consists of two words, namely maqashid and al-sharia. Maqashid means intentional or purposeful, while alsyariah means a path to a water source or as a path to the main source of life (Ahmad, 2011). The terms of the meaning of Maqashid Shari'ah that were put forward by several previous scholars include: The concept of Maqashid Shari'ah according to Al-Imam AlSyaitibi, that "Shari'ah really aims to realize the benefit of humans as servants of God in the world and the hereafter. Therefore, when His servants are burdened with obligations (alternative), it is nothing but to bring about benefit, so that in his view there is not a single law which has no purpose". Riyadi (2014), this is different from the concept of maqashid sharia according to Al-Imam AlGhazali, that" Maintaining the aims and objectives of this Sharia is a fundamental effort to survive, the damage factor cuts and encourages prosperity. "According to AlGhazali that the welfare of a society depends on hifdzun (religion), hifzhun nafs (soul), hifdzul 'aql (intellect), hifzhun nasl (descent) and hifzhul maal (wealth) whose ultimate goal is to achieve the goodness of the world and the hereafter. The benefits of al-din wa al-dunya (Karim, 2014).

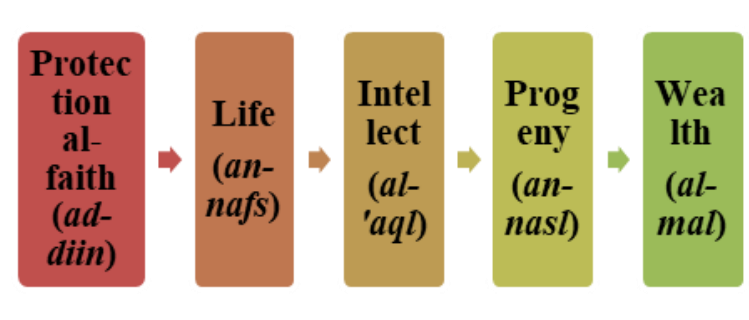

Figure 1.

Five Main Elements in Maqashid Sharia

The maintenance of these five main goals is a basic human need, namely the absolute group that must be fulfilled so that 
humans can live happily in this world and the hereafter. In addition, Imam Asy-Syaitibi has classified Maqashid Sharia into maslahah levels, namely necessity (dharuriyah), complement (hajiyah), and improvement (tahsiniyat). Karim (2014), this is as stated in QS. Al-Jatsiyah: 18 which is "Then We have made you take a course in adultery, therefore follow it, and do not follow the low desires of those who do not know"

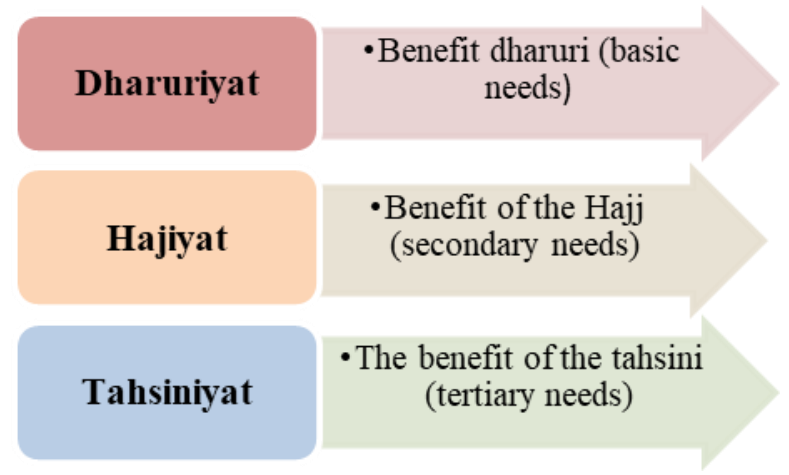

Figure 2.

Priority Scale Based on Maslahah Side

Thus Maqashid Sharia is the path to the goal of life, which is to create prosperity and benefit for all people in the world and in the hereafter. In addition, humans can obtain protection and benefit from all the provisions of sharia and are able to avoid harm (mafsadah daf'ul) and in maintaining the maqashid of sharia must pay attention to their priorities. In several studies such as Dar (2004) where Maqashid Syariah is used as an indicator of socio-economic development where policies in development will be in line with Maqashid Syariah, but both still have some differences in determining indicators that are considered capable of representing maqashid sharia. However, this research cannot be separated of the welfare approach (Dar, 2004). Syed \& Hasan (2014) are the only ones who have so far tried to make quite different measurements in socio-economic development. In addition, research that explicitly focuses on the Maqashid Sharia index was carried out by Arifqi (2020); Solihin (2019); Asmuni (2014); Rama \& Makhlan (2013) who examine related maqasyid sharia in order to formulate a development concept in accordance with Sharia.

To carry out their functions, humans need media in the form of government. Media governance is very important for humans so that human relations can be maintained properly. Humans are required to maintain harmony in all interactions and government has an important role to play in maintaining harmony.

The government has the right to intervene in the economic sector carried out by individuals, both to supervise activities carried out by economic actors and to regulate matters relating to the economy but can not be done by individuals (Mannan, 2014).

The government is the mandate holder to carry out joint tasks in realizing justice and prosperity as well as a good life order for all society. As a mandate holder, the existence and role of this government has a solid foundation in the Koran and Sunnah, both explicitly and implicitly. The role of the state is treated in the instrument and functionalization of Islamic economic values in the aspects of law, planning, planning, management and supervision. Therefore, the government as the beneficial owner of economic resources is society, including 
production and distribution as well as institutions that oversee economic life. Disturbing the government does not mean that the government has the right to monopolize all of the country's economic resources. All proceeds from government intervention aim to produce godly individuals and communities.

The text of the Koran and Sunnah explicitly and implicitly mentions the role played by the government. These roles are: 1) Punlik wealth management in order to maximize public interest. 2) Fulfill all the requirements to build a country that can effectively protect society and its cultural, economic, religious and political interests. 3) Utilizing revenue to finance public administration and government tasks. 4) Ensuring individuals can increase efficiency and the degree of wealth and welfare. 5) Maintaining social and economic balance, especially the distribution and redistribution of wealth / income. 6) Protect the economic environment so that it remains in accordance with Islamic values and principles. P3EI (2008); Qardhawi (2000) explained that the duty of the state is to change thoughts into deeds, transfer morality to concrete practices, establish various institutions and institutions that can carry out the task of guarding and developing all of these. Qardhawi, (2000), task state should also monitor the implementation of the obligations required indiscipline and punish those who are violating or ignoring harassment in a common life. Al-Ghazali provided detailed comments and advice on the procedures for state affairs.
National development is an effort to advance all aspects of the life of the community, nation and state which is at the same time the process of developing the entire state administration system to achieve national goals. In another sense, the embodiment of national development can be interpreted as a series of sustainable national development efforts which can be interpreted as a series of development efforts that carry out the task of realizing national goals. Budiyanto (2018), implementation of development embodies aspects of national life, namely political, economic, sociocultural, and national security aspects that are planned, comprehensive, and national in order to create a life that is equal and equal to others. developed countries. Therefore, in fact national development is a reflection of the willingness to continue to improve the people's welfare and the implementation of a developed country and democracy based on Pancasila (Budiyanto, 2018).

Budiyanto (2018), the essence of national development is the development of the Indonesian nation as a whole and the development of Indonesian society as a whole. This means that in implementing national development the following matters are required: First, There is harmony, harmony, balance, and unanimity in all development activities. Development for humans and non-humans for development. In today's development, the human element, socio-cultural elements, and other elements must receive balanced attention. Second, development must be fair to all communities and across the country. Third, namely the subjects and objects of development are 
the people and people of Indonesia, so development must have an Indonesian character as well. Fourth, development is carried out jointly by the community and government. The community is the main actor in development and the government is obliged to direct, guide and create a supportive atmosphere. Community activities and government activities must mutually support, complement and complement each other in one step towards achieving the goals of national development.

National development is carried out to realize national goals as stipulated in the Preamble of the 1945 Constitution paragraph IV, namely protecting all Indonesian people and all Indonesia, advancing public welfare, advancing the life of the nation, and participating in world order based on independence, eternal peace and social justice, and realizing the ideals of the nation as stated in paragraph II of the Preamble of the 1945 Constitution (Budiyanto, 2018).

Mentioned in the 2015-2019 RPJMN, the main problems faced in efforts to achieve development are: (1) Decreasing state authority, (2) Weakening of the joints of the national economy, and (3) Spreading intolerance and a national personality crisis. The main challenges of development are political and security stabilization, efficient and effective bureaucracy, eradicating corruption, increasing economic growth, accelerating equity and justice, sustainable development, improving the quality of human resources (HR) and disparities between regions, and accelerating maritime affairs. development. Seeing the main problems and challenges faced, as well as the achievements of development so far, the vision for the 2015-2019 national midterm development is the realization of a sovereign, independent, and personalitybased spirit based on mutual cooperation.

Efforts to realize this vision are spelled out through seven medium-term development missions, namely: 1) Realizing national security that is capable of maintaining regional sovereignty, sustaining economic independence by securing maritime resources, and reflecting Indonesia's personality as an archipelagic nation; 2) Realizing an advanced, balanced and democratic society based on law; 3) Creating a free and active foreign policy and strengthening its identity as a maritime country; 4) Realizing a quality, advanced, and prosperous Indonesian human life; 5) creating a competitive nation; 6) Realizing Indonesia to become a maritime country that is independent, advanced, resilient and based on the national interest; and 7) Creating a culture-oriented society.

The vision and mission of national mid-term development for 2015-2019 is further formulated in nine priority agendas or called Nawacita, namely: 1) reviving the state to protect the entire nation and providing a sense of security for all citizens; 2) Realizing a government that is always present by building a clean, effective, democratic and reliable government; 3) Developing Indonesia from the periphery by strengthening regions and villages within the framework of a unitary state; 4) Strengthening the existence of the state in reforming the system and law enforcement that is free of corruption, dignified and reliable; 5) Improve the quality 
of life of the people and society of Indonesia; 6) Increase the productivity and competitiveness of the people in the international market so that the Indonesian people can advance and rise together with other Asian nations; 7) Realizing economic independence by moving strategic sectors of the domestic economy; 8) Carry out a national character revolution; and 9) Strengthening diversity and strengthening Indonesia's social restoration.

Development norms applied in the 2015-2019 RPJMN are: 1) Development is holistic in a comprehensive manner, taking into account all related dimensions; 2) Human and community development must empower the community to be independent and not cause the community to become weak (entitled people); 3) Development does not create widening inequality; 4) Development must not damage and reduce the carrying capacity of the environment and ecosystem; and 5) Development must encourage private sector growth and not just kill existing businesses.

Some research that specifically examines economic development based on maqasyid sharia is still very rare, many of the researchers study the concept of development in general which examines the macroeconomic and microeconomic conditions of a country (Budiyanto, 2018), while other research such as Dahuri (2001); Suhardin (2012); Ahmad (2011) studied separate economic development or did not link economic development or economic growth with the concept of maqasyid sharia. In addition, research that explicitly focuses on the Maqashid Syariah index was conducted by Amiruddin (2020); Rasool et al, (2012); Bedoui, (2014); Ghazal \& Zulkhibri, (2014); Mili (2014); Kasri \& Ahmed (2015).

Based on previous research, there is a gap to be researched, namely research related to national development programs associated with maqasyid sharia to get different results or as novelty in this research. So that the final objective of this research is to examine the national development program which is based on Maqasyid sharia.

\section{METHODOLOGY}

This research uses a qualitative approach where the purpose of qualitative research is to understand the phenomenon of what is caused by the research subject, in a holistic descriptive manner in the form of words and language, in a special natural context and by utilizing various scientific methods (Moloeng, 2017). This study uses a qualitative approach because it will analyze the development program of the Indonesian government to achieve Maqashid Syariah through the application of Islamic philanthropic institutions in Indonesia, so that the analysis used is to compare or comparison, and synthesis with researchers or existing literature sources. Due to the nature of the literature review, the measurement of variables is descriptive analysis.

This research data collection technique through library research which is a technique of collecting data from various relevant reference materials and examining the issues to be discussed. Literature study is a data collection method aimed at finding 
data and information through documents such as written documents, photos, images, and electronic documents that can support the writing process (Sugiyono, 2012). Data obtained through literature study is a source of information found by competent experts in their respective fields so that it is relevant to the discussion under study (Moloeng, 2017). Due to its descriptive analysis, neither the population nor the sample were used in this study.

\section{RESULTS AND DISCUSSION}

In connection with the problem of managing national natural resources, it is necessary to look for alternatives to national development that prioritize people's sovereignty in order to realize social justice and the welfare of the wider community (Kuswandi, 2015). The alternative referred to is to refer to universal law, namely Islamic religious law, namely the theory of maqashid syari'at. The universality of maqashid shari'ah is felt, comprehensive, systemic and integral to human needs. Not only for the needs and protection of property, but includes the basic dimensions of human rights, namely heredity, mind, spirit and religion. Maqashid syari'at theory, which is considered appropriate and capable of following the current global development, is said to be a case of fiqh's proposal which reads: "keep the old and bring the new better. "In essence, the theory of maqashid syari'at is in line with the theory of social justice and people's sovereignty as referred to in the Pancasila ideology and the 1945 Constitution. Maqashid syari'ah as a legal epistemology is an important discussion in Islamic law, as one of the ijtihad methods that have been developed by scholars. several centuries ago and is the result of brilliant achievements in the field of legal thought.

With al-maqashid sharia as one of the epistemologies of Islamic law, it is hoped that it will be able to build laws that are able to function in realizing "jalb al-mashalih wa daf'u al-mafasid" so as to create stability in life, realize justice, benefit and prosperity in human life in world and al-fauz bi al-jannah wa an-najat min an-naar which means in the hereafter and that is the highest benefit for humans and that is the essence of maqashid shari'ah.

According to Umar Capra in Katmas (2018) about the economy in perspective maqashid al-Sharia, which is one element of the nation or the state of development described in Table 1. The role of the Indonesian government in maintaining the maqashid of sharia through programs or policies carried out by the government. In the formation and implementation of the program, a National and Regional MediumTerm Development Plan has been drawn up, which the plan is used as a reference in making programs by various ministries and related institutions that are responsible in their respective fields. Development in Indonesia is a sustainable development that has several stages, at this time the development stage is in the second stage, which is known as the 2015-2019 RPJMN. 
Table 1.

Mashid Syariah in State Development

\begin{tabular}{ll}
\hline \multicolumn{1}{c}{ Maqashid Sharia } & \multicolumn{1}{c}{ Implementation } \\
\hline Keeping Religion (Ad-din) & $\begin{array}{l}\text { Religion is also able to motivate and subdue one's personal preferences by } \\
\text { prioritizing social interests which are based on togetherness, kinship and } \\
\text { creating a conducive environment to strengthen social solidarity and } \\
\text { cooperation between individuals. }\end{array}$ \\
\hline Guarding the Soul (An-Nafs) & $\begin{array}{l}\text { Soul care and development can be done by meeting its primary needs. The main } \\
\text { need is not only to ensure the survival of his soul and welfare, but to be able to } \\
\text { carry out his role as caliph effectively. Good governance for social and political } \\
\text { stability, availability of necessities of life, availability of employment } \\
\text { opportunities, and so on. }\end{array}$ \\
\hline Keeping Intellect (Al Aql) & $\begin{array}{l}\text { Intellect is a very large gift that distinguishes each human being and needs to be } \\
\text { improved to improve the welfare of individuals and others. To support good } \\
\text { quality of reasoning, quality education at affordable prices must be provided, } \\
\text { freedom of thought and expression and recognition for work performance. }\end{array}$ \\
\hline Maintaining & Vocational \\
Education (An Nasl) & $\begin{array}{l}\text { To build a good and sustainable civilization, moral education must be instilled } \\
\text { from childhood. According to Umer Chapra, preserving offspring can be done } \\
\text { by way of marriage and family with integrity, improving maternal health and } \\
\text { adequate nutrition for children's growth and development, finding the } \\
\text { necessities of life, ensuring the availability of bursts of economic energy for } \\
\text { present and future generations, a healthy and clean environment. and sustainable } \\
\text { development. }\end{array}$ \\
\hline Keeping Treasure (Al Mal) & $\begin{array}{l}\text { Property is very important to support the four elements of the maqashid sharia } \\
\text { above, because without the assets of the four maqashids above, it does not work } \\
\text { well. According to Chapra, there is one consequence of the development of } \\
\text { assets, namely that humans have the right to enrich economic resources as a } \\
\text { means to meet the needs of life, but contain social functions because they have } \\
\text { to share these rights with others or entirely. Public. }\end{array}$ \\
\hline
\end{tabular}

Source: Katmas (2018)

The vision of national development for 2015-2019 is the realization of development that is Sovereign, Independent, and with a Personality based on mutual cooperation. The national development strategy in the 2015-2019 RPJMN is described in three dimensions of development, namely the Human and Community Dimensions, Main Sector Development Dimensions \& Equality and Territorial Dimensions, which are supported by the necessary conditions related to politics, law, defense and security aspects. Furthermore, in the 2015-2019 RPJMN, nine priority agendas were formulated or called Nawacita. Meanwhile, the main targets of national development in realizing the development vision include: (1) Macro Targets; (2) Human and Community Development Goals; (3) Leading Sector Development Goals; (4) Target Equity Dimension; (5) Regional and Inter-Regional Development Targets; and (6) Political, Legal, Defense and Security Goals.

Based on these various targets, there are many government programs that have been implemented both at the national and regional levels. Because there are so many 


\author{
programs in this journal that only discuss \\ programs that are in accordance with \\ maqashid sharia.
}

An explanation of the maintenance of Maqashid Sharia through Indonesian government programs can be seen in Table 2 .

Table 2.

Implementation of Government Programs in the Maqashid Sharia Review

\begin{tabular}{|c|c|c|}
\hline Maqashid Sharia & $\begin{array}{c}\text { Government } \\
\text { Programs } \\
\end{array}$ & Description \\
\hline $\begin{array}{l}\text { Keeping Religion } \\
\text { (Ad-din) }\end{array}$ & $\begin{array}{l}\text { Bimas Islam } \\
\text { (Directorate General of } \\
\text { Islamic Community } \\
\text { Development) }\end{array}$ & $\begin{array}{l}\text { Preservation of religion is carried out through the implementation of } \\
\text { programs that can maintain worship activities both to God and } \\
\text { humans such as alms, alms and the like. In this case, Islamic } \\
\text { Community Development is only one of the many government } \\
\text { administration programs that function and are capable of guarding } \\
\text { the religion of the people whose duties are to carry out the } \\
\text { formulation and implementation of policies in the field of fostering } \\
\text { Muslims in accordance with statutory provisions. }\end{array}$ \\
\hline $\begin{array}{l}\text { Guarding the Soul } \\
\text { (An-Nafs) }\end{array}$ & $\begin{array}{l}\text { Health Development } \\
\text { Policy by strengthening } \\
\text { quality Primary Health } \\
\text { Services. }\end{array}$ & $\begin{array}{l}\text { Several programs to protect lives are through health services } \\
\text { implemented through various programs such as Accelerating the } \\
\text { Fulfillment of Quality Health Services for Mothers, Children, } \\
\text { Adolescents and the Elderly, Accelerating Community Nutrition } \\
\text { Improvement, Improving Disease Control and Environmental } \\
\text { Health, Increasing Access to Quality Basic Health Services , } \\
\text { Increasing Access to Quality Referral Health Services, } \\
\text { Increasing Availability, Affordability, Equity and Quality of } \\
\text { Pharmaceutical Preparations and Medical Devices, Increasing } \\
\text { Control of Drugs and Food 8. Increasing Availability, } \\
\text { Distribution and Quality of Human Resources for Health, Increasing } \\
\text { Health Promotion and Community Empowerment, Strengthening } \\
\text { Management, Development of Research and Information Systems, } \\
\text { Strengthening Implementation of the National Social Security } \\
\text { System (SJSN) in the Health Sector, Development and Increasing } \\
\text { the Effectiveness of Health Financing. }\end{array}$ \\
\hline $\begin{array}{l}\text { Keeping Intellect (Al } \\
\text { Aql) }\end{array}$ & $\begin{array}{l}\text { Ministry of Education } \\
\text { and Culture through } \\
\text { programs of students, } \\
\text { teachers, parents, } \\
\text { schools, culture and } \\
\text { language, society, local } \\
\text { government. }\end{array}$ & $\begin{array}{l}\text { Preservation of reason can be done through education. Various kinds } \\
\text { of programs implemented by the Indonesian government in } \\
\text { improving the quality of its people through the preservation of } \\
\text { reason, such as the existence of an education system and assistance } \\
\text { in its implementation ranging from primary, secondary and tertiary } \\
\text { education, to the administration of formal, informal, early childhood } \\
\text { education. education, official education namely professional } \\
\text { education, religious education, distance education, special education } \\
\text { and special services. }\end{array}$ \\
\hline $\begin{array}{ll}\text { Keeping } & \text { Treasure } \\
\text { (Al Mal) } & \end{array}$ & $\begin{array}{lr}\text { Monetary } & \text { and fiscal } \\
\text { stability } & \text { policies to } \\
\text { maintain } & \text { economic } \\
\text { stability. } & \end{array}$ & $\begin{array}{l}\text { Asset security is carried out by the Government of Indonesia through } \\
\text { monetary and fiscal policies so as to create economic stability in } \\
\text { terms of the price policy for goods services, the monetary system } \\
\text { used, as well as a positive and internationally competitive economic } \\
\text { ecosystem. In addition, there are facilities for Muslims to safeguard } \\
\text { their assets through Islamic financial instruments such as zakat and } \\
\text { waqf (the existence of zakat and waqf), alms, alms and others. }\end{array}$ \\
\hline
\end{tabular}

Sumber :Katmas (2018) 
The first is to maintain a gama (Ad din). In this case BIMAS Islam is in the middle of the Ministry of Religion in which there is a program that tends to guard religion. the function of the Directorate General of Islamic Community Development itself, namely to formulate policies in the field of fostering Muslims; the implementation of the Muslim community development program which includes fostering the religion of Islam and sharia, the formation of religious and family services, counseling on Islamic religion, empowering zakat, and empowering waqf; formulating norms, standards, procedures and criteria in the field of fostering Muslims; implementation of providing technical guidance and evaluation in the field of fostering Muslims; and administration of the Directorate General of Islamic Community Development.

In the 2018 performance report of the Directorate General of Islamic Community Guidance, the first quarter of the 2018 fiscal year, Islamic Community Guidance succeeded in implementing several programs which in their implementation also automatically impacted the maintenance of Religion (Ad din). The program is an Islamic religious education that has been facilitated by 21,679 extension workers, both civil servants and non civil servants. Facilitating mosques in order to protect the community so that they can carry out their religious obligations, the achievements reached 18 mosques and 14 mushallas. There are main performance indicators that run in the first quarter but have not yet been able to produce results because they are only in the process of drafting regulations including 145 targets for the number of socio-religious institutions that are facilitated in meeting the minimum standards of religious institutions, 2,968 KUA have met service standards in religious administration services, with a target of 149,646 bride and groom get marriage coaching facilities. With these programs the community will be able to maintain their faith and religion maximally both in the implementation of their worship and their muamalah based on Islamic law.

Guarding the Soul (An Nafs). Mental care can be done through public health services because by maintaining community health, the soul will also be well preserved. Several government programs through the Ministry of Health of the Republic of Indonesia in the 2019 evaluation include the Healthy Indonesia Card and the National Health Insurance Program which reached 109.9 million people, nutrition development programs and maternal and child health. where $85 \%$ of deliveries have been facilitated and a decrease in the percentage of pregnant women with chronic energy deficiency which is currently only $18.2 \%$, disease control and health and environmental programs, health service development programs, pharmaceutical and medical devices programs, health development and empowerment programs for professionals health) doctors who completed on time reached 167,000 . The percentage of 
districts / cities that meet environmental health quality is $40 \%$. b. The percentage reduction in cases of certain diseases that can be prevented by immunization (PD3I) is $40 \%$. c. The percentage of districts / cities that have preparedness policies for public health emergency response that have the potential for outbreaks is $100 \%$.

The percentage reduction in the prevalence of smoking at 18 years of age was $5.4 \%$. The percentage of districts / cities that implement integrated vector control is $80 \%$. b) The number of districts / cities with API $<1 \%$ is 75 districts / cities. d) Percentage of districts / cities with DHF <49 per 100,000 population is $68 \%$.e) The percentage of districts / cities that eradicate rabies is $85 \%$. The number of villages / wards implementing STBM is 45,000 villages / wards. b) The percentage of drinking water facilities under supervision is 50\%.c) Percentage of public places that meet health requirements is $58 \%$.d) Hospitals that manage medical waste according to standards are $36 \%$. e) Percentage of Food Management Places (TPM) that meet health requirements is $32 \% . \mathrm{f})$ The number of districts / municipalities that organize healthy area spatial planning is 386 villages / wards. The number of sub-districts that have at least 1 accredited Puskesmas is 5,600 subdistricts. b. Districts / cities that have at least 1 RSUD certified with national accreditation are 481 districts / cities.

Keeping Intellect (Al Aql). Preservation of reason can be done through education. The 2018 State Budget provides funds of IDR 2,220.1 trillion for the education sector itself, both for transfers to the regions, the Ministry of Education and Culture, the Ministry of Education and Culture, the Ministry of Education, and other education budgets. Various kinds of programs implemented by the Indonesian government in improving the quality of its people through the preservation of reason, such as the School Operational Assistance Fund (BOS), which is a government program to help provide school operational costs from SD to SMA / SMK levels. / MA level. This program really helps students so they don't have to pay expensive school fees, especially in public schools. In addition, there is the Smart Indonesia Card program, which is a form of the Smart Indonesia Program intended for students who cannot afford cash assistance to help school needs in educating. Then there are healthy educational programs that provide services or facilities regarding educational material in various fields and levels provided in the form of website technology and can be accessed or used by anyone. Similar to the learning house which is a program of the Ministry of Education and Culture, a learning portal that provides learning materials and communication facilities that support interaction between communities. Rumah Belajar is present as a form of learning innovation in the industrial era 4.0 that can be used by students and teachers of Early Childhood Education (PAUD), Elementary Schools (SD), Junior High Schools (SMP), Senior High Schools / Vocational Schools. (SMA / SMK) or equivalent. By 
using Rumah Belajar, we can study anywhere, anytime with anyone. All content in Rumah Belajar can be accessed and used free of charge. In this program there are 224,394 teachers and 554,971 students.

A more comprehensive formulation of the National Examination in order to improve the quality of human resource standards in Indonesia. The existence of the National Examination will increase human thinking and thinking power. The certification program for teaching staff is also increasingly stringent and of high standard and involves the latest technology, this is done to help improve the quality of Human Resources. There is also a family friends program that is presented in the form of a website through this website which is expected to build an educational ecosystem consisting of parents, principals, teachers, school committees, education boards, education activists and the whole community. who is smart and has character. Through this page, parents can also get good family education practices and pass it on to other parents so that it can become a shared learning facility. Parents can also learn from the experiences of other parents who have succeeded in educating their children until they are successful.

Maintain offspring (An Nasl). Marriage is a form of human guardian in maintaining or maintaining offspring. One of the government's program efforts to facilitate the fulfillment of the care of offspring by improving the quality of KUA. The program that is currently being implemented is a certification for prospective brides. Prenuptial certification will add insight and quality to the prospective bride and groom, which includes material about educating children and health for families and children. In addition, the development of offspring is also carried out by the Ministry of Health with several achievements such as the percentage of puskesmas that carry out adolescent health activities by $45 \%$, and the percentage of puskesmas implementing mother class by $90 \%$. Puskesmas that provide antenatal services at least 4 times (K4) is $80 \%$, the percentage of children aged 0-11 months who get complete basic immunization is $93 \%$, the percentage of availability of drugs and vaccines at the puskesmas is $90 \%$, the amount of raw materials for traditional medicines and medicines and medical devices (medical devices) that are produced domestically are 35 percent, the percentage of circulating medical devices and PKRT products that meet the requirements is $83 \%$.

In addition, the stunting rate in Indonesia is quite high, this is quite a threat to the health of toddlers and children. So that there is a special nutrition intervention program to overcome this problem by providing additional food to pregnant women from poor groups by providing additional blood supplements, calcium and free antenatal care. For breastfeeding mothers and children aged 0-23 months 24-59 months, vitamin A supplementation, taburia supplementation, diarrhea treatment personnel, immunization, integrated 
management of hospital balia (MTVS), growth and development monitoring, supplementary feeding for children for malnutrition For adolescents and women of childbearing age, supplementation with additional blood tamblets, vitamin A. Health (JKN), Access to Cash Assistance for Underprivileged Families (PKH), Access to Non-Cash Food Assistance (BPNT) for underprivileged families, access to fortification of staple foods (salt, wheat flour, cooking oil), access to Sustainable Food House Activities (KRPL). And there are many government programs that have succeeded in helping people or humans protect and maintain their minds.

Safeguarding Property (Al Mall). A form of asset security carried out by the state through monetary and fiscal policies aimed at maintaining economic stability. Some of the monetary measures taken by the Government of Indonesia are 1) Increasing the coordination of policy stakeholders to increase the effectiveness of policies at the central and regional levels, among others through the Inflation Control Team (TPI), Regional TPI, and Macro Assumption Team; 2) Strengthening structural policies to support sustainable economic growth, including the implementation of the roadmap for reducing fuel subsidies in line with the conversion of renewable energy consumption to a more environmentally friendly manner, policies in the financial sector, particularly financial market deepening, and policies in the real sector.;3) Improve discipline in maintaining the stability and sustainability of economic growth; 4) Strengthening a strong policy response to support a sound corporate financial system and balance sheet; and 5) Increase intensive communication to anchor market perceptions.

The following are some of the achievements that have been made by the government through various programs: 1). Economic growth is quite high compared to other countries, but global uncertainty has caused the Indonesian economy to not grow as targeted.(5.02\%). 2). Decreased poverty rate $(10.70 \%)$. 3). Open unemployment decreased (5.61\%). 4). Inflation can be controlled within the target range to maintain people's purchasing power (3.02\%). 5). Rupiah exchange rate was lower than previously estimated due to the global economic crisis (IDR 13,307 / USD). 6). Non-oil and gas export growth was still negative due to weakening global demand and falling commodity prices (0.29\%). 7). Foreign exchange reserves were still deep months of imports are still above the safe limit (8.30 months). 8). The realization of PMA and PMDN has exceeded the target in the last two years (Rp612.80T). 9. ) Domestic investment ratio is in the expected trend $(35.28 \%)$

Of course, apart from maintaining the macro level, the government continues to carry out personal safeguards such as increasing financial literacy for the public, facilities and easy access to banking institutions and other non-bank financial institutions. The existence of Islamic financial institutions and social finance that make it 
easy for people to maintain property in accordance with the provisions of Islam

\section{CONCLUSIONS AND SUGGESTIONS}

The government is the mandate holder to carry out joint tasks in realizing justice and prosperity as well as a good life order for all society. As a mandate holder, the existence and role of this government has a solid foundation in the Koran and Sunnah, both explicitly and implicitly. The role of the state is treated in the instrument and functionalization of Islamic economic values in the aspects of law, planning, planning, management and supervision. Therefore, the government as the beneficial owner of economic resources is the community, including production and distribution as well as life regulatory agencies. This interference with the government does not mean that the government has the right to monopolize all of the country's economic resources. All the results of government intervention are aimed at producing religious individuals and communities.

Indonesia through its government policies and programs has succeeded in maintaining 5 elements of maqashid sharia, namely hifdzun in (Religion), hifzhun nafs (Jiwal), hifdzul 'aql (Intellect), hifzhun nasl (descent) and hifzhul maal (wealth) which means that the Indonesian nation has a good opportunity. able to achieve goodness in this world and the hereafter. However, Indonesia is a very large country, so the process of achieving maqashid sharia safeguards requires extra manpower so that it can be achieved $100 \%$ by all Indonesian citizens. At present, efforts are still being made to achieve the program and the resolution of government problems, both central and regional governments, so that the percentage of achievement varies from various programs. The number of government programs cannot be fully discussed in this study so there is a need for further discussion of other government programs that are able to guard the five elements of maqashid sharia.

\section{REFERENCES}

Ahmad, Agustan. (2011). MaqāṢid al-syarī’ah alsyāṬib̄̄ dan Aktualisasinya dalam nilai-nilai falsafah Pancasila Hunafa. Jurnal Studia Islamika. 8(2), 217-235.

Amiruddin. (2020). Maqasid Al Syariah Dalam Filsafat Hukum Islam. Darussalam : Jurnal Ilmiah Islam dan Sosial, 21(2), 61-70

Arifqi, Moh. Musfiq (2020). Rekonstruksi Teori Maqasid Syariah Sebagai Konsep Pembangunan Ekonomi Islam Di Indonesia (Analisis Pendekatan Pemikiran Jasser Auda). Jurnal Keislaman Terateks. 5 (1),50-60

Asmuni, MTH. (2014). Strategi Pembangunan Ekonomi Berbasis Sistem Al-Maqashid. Millah Vol. XIV, No. 1, Agustus 2014.

Bedoui, H. E. (2014). Socio-economic Development Index based on Maqasid al-Shari'ah. International Thematic Workshop on Developing Maqasid Al-Shari'ah based. Measurement of Socio-economic Development. Jeddah, Saudi Arabia: Islamic Research and Training Institute (IRTI), Islamic Development Bank

Budiyanto. (2018). Kewarganegaraan. Jakarta: Erlangga.

Chapra, M. (2000). Islam dan tantangan ekonomi. Terjemahan dari Islam and The economic challenge. Ikhwan Abidin Basri. Gema insani press.

Dahuri, Rokhimin (2001). Pengelolaan Ruang Wilayah Pesisir Dan Lautan Seiring Dengan 
Pelaksanaan Otonomi Daerah. Jilimbar, XVII (2), 139-171

Dar, H. (2004). On Making Human Development More Humane. International Journal of Social Economics, 31(11), 2071-1088.

Fuad, Fokky (2012). Islam Dan Ideologi Pancasila, Sebuah Dialektika. Lex Jurnalica. 9(3), 164170

Ghazal, R., \& Zulkhibri, M. (2014). Islamic Inclusive Growth Index (i-IGI): Measurement and Determinants. International Thematic Workshop on Developing Maqasid AlShari'ah based Measurement of Socio-economic Development (pp. 239-260). Jeddah, Saudi Arabia: Islamic Research and Training Institute (IRTI), Islamic Development Bank.

Karim, A. (2014). Sejarah Pemikiran Ekonomi Islam. Jakarta :Raja Grafindo Persada.

Kasri, R. A \& Ahmed, H. (2015). Assessing SocioEconomic Development based on Maqasid alShari'ah Principle: Normative Frameworks, Methods and Implementation in Indonesia, Islamic Economis Studies, 23(1), 73-100

Katmas, E. (2018). Analisis Program Pengentasan Kemiskinan di Kecamatan Toyando Tam Perspektif Mqashid Al-Syariah. Master Thesis. Malang :UIN Maulana Malik Ibrahim.

Kuswandi, (2015), Model Pengelolaan Sumber Daya Alam Untuk Sebesarbesarnya Kemakmuran Rakyat. Jurnal Mimbar Justitia, I(2), 518-531

Mannan, M. A. (2014). Hukum Ekonomi Syariah. Jakarta: Kencana Prenada Media Group.

Mili, M. (2014). A Structural Model for Human Development: Does Maqasid Al-Shari'ah Matter? International Thematic Workshop on Developing Maqasid Al-Shari'ah based Measurement of Socio-economic Development (pp. 283-300). Jeddah, Saudi Arabia: Islamic Research and Training Institute (IRTI), Islamic Development Bank.

Moloeng, L. (2017). Metodologi Penelitian Kualitatid Edisi Revisi. Bandung : Remaja Rosdakarya.

P3EI. (2008). Ekonomi Islam. Yogyakarta: Fakultas Ekonomi Universitas Gadjah Mada

Qardhawi, Y. (2000). Ijtihad Kontemporer, kode etik dan berbagai penyimpangan. Terjemahan abu Barzani. Surabaya : Risalah Gusti.

Rama, Ali., \& Makhlan, (2013). Pembangunan Ekonomi Dalam Tinjauan Maqashid Syari'ah. Dialog. 36(1), 31-46

Rasool, M. S. A., Shalleh, A. M., \& Harun, M. F. M. (2012). Poverty Measurement by Islamic Institutions. International Journal of Social, Behavioral, Educational, Economic, Business, and Industrial Engineering, 6(5), 489-491

Riyadi, I. (2014). Prinsip Dasar Ekonomi Islam Perspektif Maqashid al-Syariah. Jakarta : Kencana Prenada Media Group.

Solihin, K., Ami'in, S. N., \& Lestari, P. (2019). Maqashid Shariah Sebagai Alat Ukur Kinerja Bank Syariah Telaah Konsep Maqasid Sharia Index (Msi) Asy-Syatibi. LAA MAISYIR. 6(2), $148-170$

Sugiyono. (2012). Metode Penelitian Kuantitatif Kualitatif dan RND. Bandung :Alfabeta.

Suhardin, Yohanes. (2012). Peranan Negara Dan Hukum Dalam Memberantas Kemiskinan Dengan Mewujudkan Kesejahteraan Umum. Jurnal Hukum dan Pembangunan. 42(3), 302317

Syed, A.S., \& Hasan, H. (2014). Towards a Maqasid al-Shariah based Development Index. The Islamic Research and Teaching Institute. 